\title{
Tuberculous Meningitis in Two-Year-Old Male Boy: Evidence of Recent Transmission from Mother to Baby
}

\author{
Anneden Çocuğa Bulaşmanın Kanıtı Olarak Tüberküloz Menenjitli İki Yaşında \\ Erkek Çocuk
}

Shital Patil' ${ }^{1}$ Nilesh Nagargoje ${ }^{2}$, C. R. Choudhary ${ }^{3}$

\section{Abstract}

Tuberculous (TB) meningitis is the commonest infectious disease of central nervous system in pediatric and geriatric cases. Tuberculosis can be prevented in children by diagnosing and treating cases of active TB amongst adults, as pediatric cases always acquire it passively from household contact of adults suffering from TB as disease in adults is multibacillary. Although significant data is available for the prevention of childhood extra-pulmonary and disseminated TB, offering them Bacillus Calmette-Guerin (BCG) vaccination, it is still not routinely offered during vaccination. In this case report, a two-year child with a history of failure to thrive and constitutional symptoms diagnosed with disseminated extra-pulmonary TB presenting as TB meningitis with a history of contact with the mother suffering from active sputum positive pulmonary TB receiving anti-TB treatment. In conclusion, we recommend BCG vaccination to all newborns, and tuberculin skin testing and isoniazid prophylaxis to the contact of adults with sputum positive pulmonary TB cases in India.

Key words: Tuberculous meningitis, BCG Vaccination, isoniazid, tuberculin skin test, recent transmission, mother to child.

\section{Özet}

Tüberküloz menenjit, pediatrik ve geriatrik olgularda en sık görülen santral sinir sistemi enfeksiyonudur. Pediatrik olgular, basil yayan erişkin tüberküloz hastaları ile yakın temas sonucu hasta oldukları için aktif erişkin tüberküloz olgularının tanı ve tedavilerinin yapılması ile çocukların bu hastalıktan korunması mümkün olabilir. Çocukluk çağında yapılan BCG aşılanması ile akciğer dışı ve yaygın tüberkülozdan çocukların korunduklarına dair anlamlı veriler bulunmasına rağmen, halen aşılama rutin olarak yapılmamaktadır. Bu olgu sunumunda, gelişme geriliği ve konstitüsyonel semptomları olan ve yaygın akciğer dışı tüberkülozun menenjit formunda ortaya çıktığı, iki yaşındaki çocuk sunulmuştur. Çocuğun tüberküloz yakın teması olarak annesinin yayma pozitif akciğer tüberkülozu olduğu ve antitüberküloz tedavi aldığı belirlenmiştir. Sonuç olarak, Hindistan'da, tüm yeni doğanlara BCG aşısı yapılmasını ve yayma pozitif akciğer tüberkülozlu erişkinlerin temaslılarının tüberkülin testinin yapılarak isoniyazid proflaksisine alınmasını tavsiye ediyoruz.

Anahtar Sözcükler: Tüberküloz menenjit, BCG aşısı, isoniyazid, tüberkülin deri testi, anneden çocuğa bulaşma.
'Department of Pulmonary Medicine, MIMSR Medical College, Latur, Maharashtra, India

${ }^{2}$ Department of Internal Medicine, Government Medical College, Latur, Maharashtra, India

${ }^{3}$ Department of Pulmonary Medicine, Dr. S.N. Medical College, Latur, Maharashtra, India
'MIMSR Tıp Fakültesi, Göğüs Hastalıkları AD, Latur, Maharaştra, Hindistan

${ }^{2}$ Devlet Tıp Fakültesi, İç Hastalıkları AD, Latur, Maharaştra, Hindistan

${ }^{3}$ Dr. S.N. Tıp Fakültesi, Göğüs Hastalıkları AD, Latur, Maharaştra, Hindistan

Submitted (Başvuru tarihi): 11.04.2016 Accepted (Kabul tarihi): 21.09.2016

Correspondence (iletişim): Shital Patil, Department of Pulmonary Medicine, MIMSR Medical College, India

e-mail: drsvpatil1980@gmail.com 
The World Health Organization (WHO) current estimates in 2015 are that one million children currently suffer from TB worldwide ( $<15$ years), and that more than 136,000 die each year (1). Many people believe that these numbers underestimate the true extent of the problem (2). About 70 to $80 \%$ of children with TB have the disease in their lungs (pulmonary TB). The rest are affected by TB disease in other parts of their body (extra-pulmonary TB). In the high-burden TB setting, it has been reported that 15 to $20 \%$ of all TB cases are among children, whereas in the low-burden TB setting, it is estimated that 2 to $7 \%$ of all TB cases are among children (2).

Tuberculous meningitis is a common infectious disease of the central nervous system in developing countries. Early diagnosis and treatment with chemotherapy and active management of the complications are of utmost importance to prevent the irreversible neurological sequelae and death. Delay in diagnosis and in the start of effective treatment results in poor prognosis and sequela in up to $25 \%$ of cases (3).

\section{CASE}

A 2-year-old male referred to outdoor of pulmonary medicine department from pediatric department with history of fever, and failure to thrive since three months, and mother of child was on anti-TB treatment for three months. Overall physical examination revealed that child was malnourished with scanty hypopigmented hairs over the scalp and most important clinical sign increases the head circumference of the child with open wide anterior fontanel, and multiple enlarged non-tender, discrete subcentimetric cervical lymph nodes present bilaterally. Neurological examination of the child suggests delayed gross and fine motor signs development with few gross motor signs showing neuroregression. Neck rigidity was positive with Kernig's sign positive. Additionally, plantar reflexes showed extensor response and deep tendon reflexes showed exaggerated response. Respiratory system examination findings are apparently normal.

The mother of the child was suffering from sputum positive pulmonary TB and is on supervised chemotherapy as per National guidelines containing four ATT (anti-TB) drugs Isoniazid, Rifampin, pyrazinamide and Ethambutol. She is having respiratory symptoms for four months before initiation of anti-TB treatment, means that baby was exposed to open TB case for four months before start of treatment. She had completed treatment when baby was 14 month old. Isoniazid prophylaxis to child irrespective of contact with sputum positive pulmonary TB case was not offered, and tuberculin skin test screening was not done.

Plain chest $X$-ray of mother before initiation of anti-TB treatment is at Figure 1. A sputum examination acid fast bacillus (AFB) of the mother before initiation of treatment was $3+$. After two months of intensive phase of chemotherapy, sputum conversion occurred and sputum for AFB was negative. Sputum conversion remained after completion of ATT for six months as per national guidelines. Chest X-ray was not done after the completion of ATT, as radiological response is not analyzed routinely in supervised regimen, only bacteriological response is assessed. Chest $X$-ray of child is performed in indoor unit is at Figure 2. We performed gastric aspirate for AFB consecutively on five days and collected early morning overnight fasting sample collected with $10 \mathrm{~mL}$ of normal saline and assessed after centrifugation of sample. Acid fast bacilli were detected in sample.

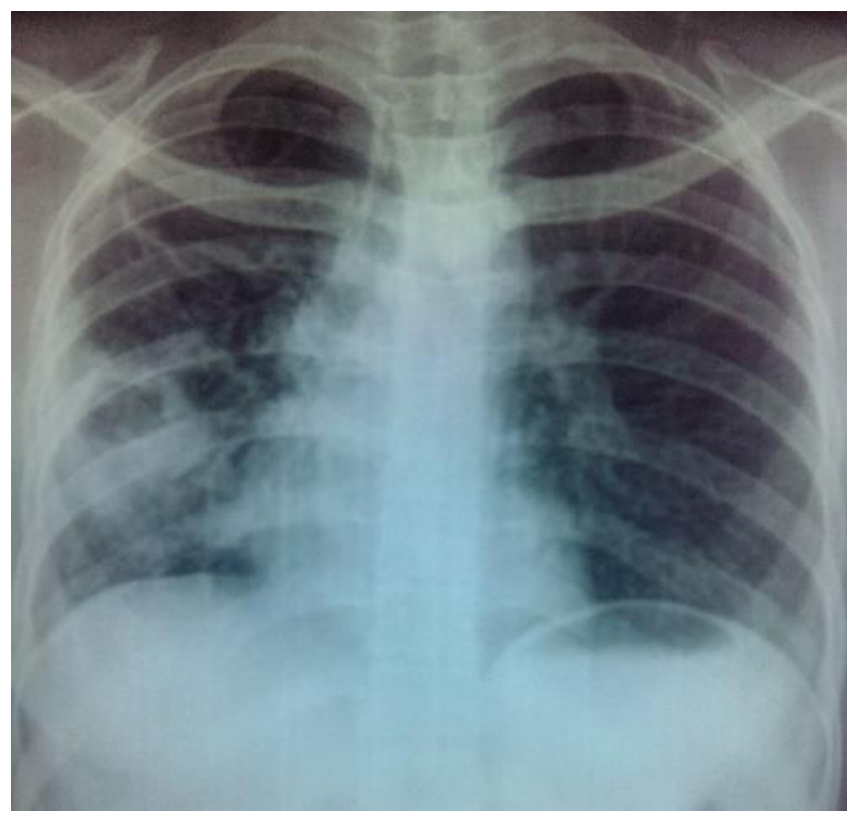

Figure 1: Plain chest $X$-ray view of mother showing 'thick walled cavity with pericavity consolidation with satellite nodules in right middle and lower zone' is an indicator of active pulmonary tuberculosis

Tuberculin skin testing was done with five TU (tuberculin unit) of PPD (purified-protein derivative) given intradermal over volar aspect of left forearm and results were observed after 48 hours after test. Tuberculin test was positive with induration of $14 \mathrm{~mm}$.

We performed computed tomography of brain plain and with contrast (Figure 3 and 4) to look for signs of tuberculous meningitis and its complications. Figures 3 and 4 showing mild dilation of ventricle system seen, i.e. mild hydrocephalous. Also note mild cortico-cerebral atrophy. 
All these features suggestive of infective etiology and TB needs to be ruled out.

We performed cerebrospinal fluid examination and results were observed as:

-Proteins- $110 \mathrm{gm} \%$

-Glucose- 56 mg\%

-Total nucleated cells $-428 / \mathrm{mm}^{3}$

-Differential cell count on smear- $90 \%$ lymphocytes and $10 \%$ neutrophils

-Gram staining and Ziehl-Neelsen staining were inconclusive

-ADA (adenosine deaminase level) in cerebrospinal fluid24 units/liter

Blood sugar level is $110 \mathrm{mg} \%$.

Complete blood counts were as follows:

Hemoglobin $8.6 \mathrm{gm} \%$, total white blood cells counts $6000 / \mathrm{mm} 3$, predominant lymphocytes on differential counts, platelets were 4.5 lacs.

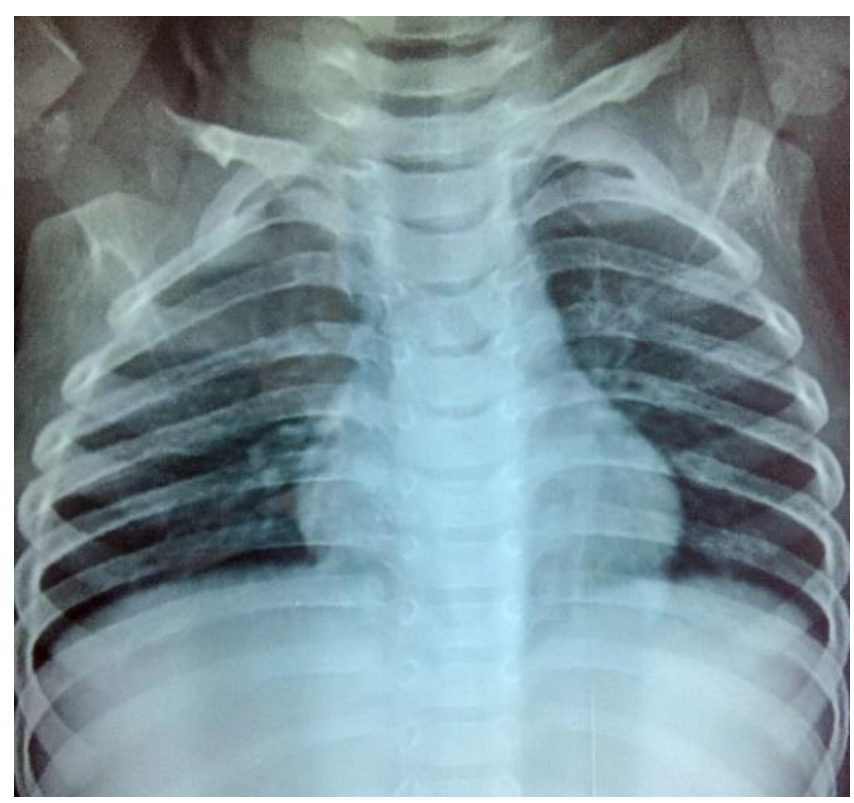

Figure 2: Anterio-posterior chest X-ray view of child showing 'bilateral hilar enlargement with bilateral discrete randomly placed nodular opacities' predominantly in lower fields and paracardiac regions.

The child was started on anti-TB treatment consisting of four anti-TB drugs Isoniazid, rifampin, pyrazinamide, and streptomycin on the day of admission as per body weight. No cerebral decongestants were required as anterior fontanel was open. In addition to anti-TB drugs, we started dexamethasone and continued it for four weeks in tapering dosages. No seizures or any neurodeficit was observed during hospitalization with complete tolerance and compliance to all three oral anti-TB drugs and one parenteral drug. We discharged child after 20 days of hospitalization with adequate weight gain and advice for compliance and adherence of ATT with high protein diet. We followed child for near complete response to chemotherapy. After four weeks steroids and streptomycin for 90 days discontinued and the rest three oral drugs were continued until six months. After 24 weeks, isoniazid and rifampin were continued until 12 months of initiation of treatment. Response to ATT is excellent with complete radiological clearance of dilated ventricles on $\mathrm{CT}$ brain and no residual neurological deficit clinically.

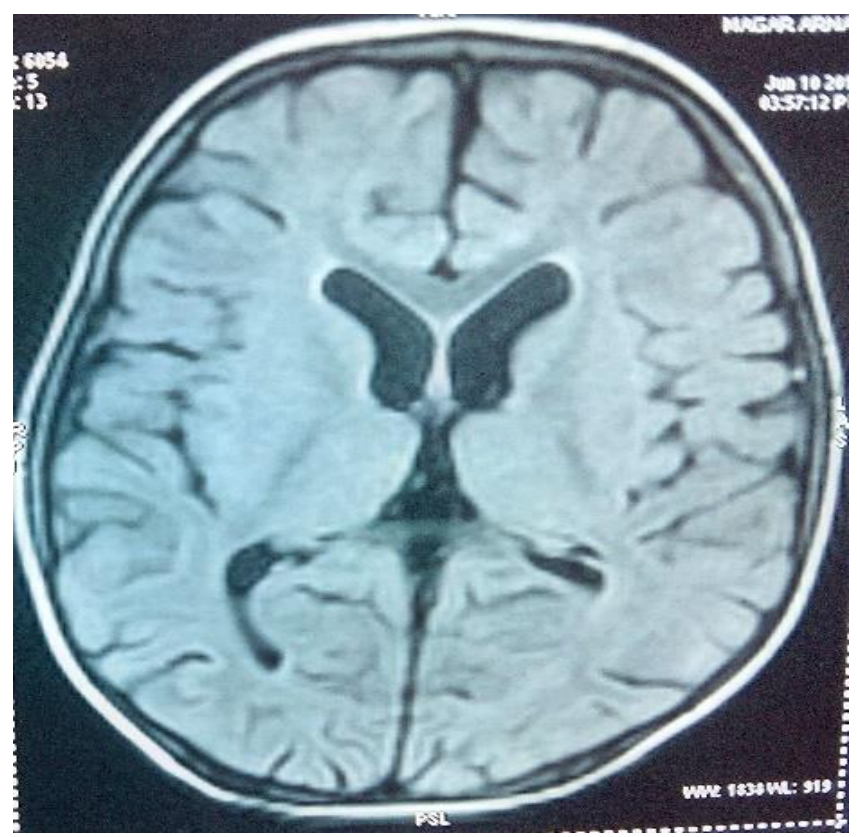

Figure 3: Plain cranial CT (non-contrast)

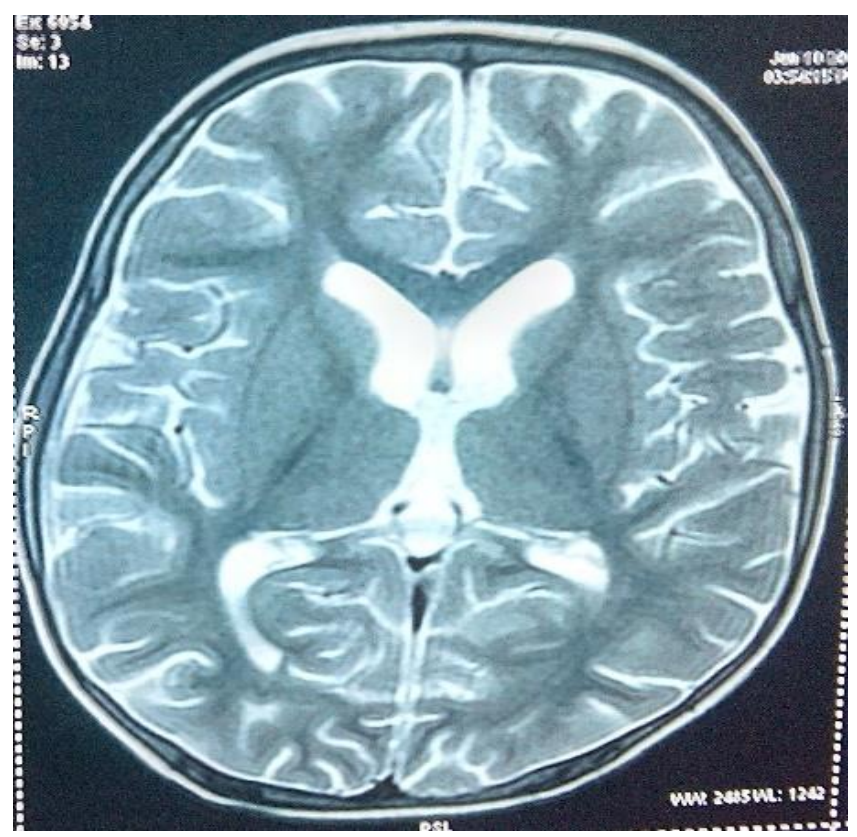

Figure 4: Contrast-enhanced cranial CT

\section{DISCUSSION}

Tuberculous meningitis occurs mainly in developing countries where tuberculosis TB is more common and the 
wider incidence of the human immunodeficiency virus (HIV) favors the onset of a great number of cases. Children are among the subjects who most frequently suffer from TBM due to their relative inability to contain primary mycobacterium tuberculosis infection in the lung (4). Tuberculous meningitis is a devastating disease with about 30\% mortality in the most severe forms; moreover, $50 \%$ of survivors have neurological sequelae, despite apparently adequate administration of antibiotics (5).

Tuberculous meningitis develops in two steps. Mycobacterium tuberculosis bacilli enter the host by droplet inhalation. Localized infection escalates within the lungs with dissemination to the regional lymph nodes. In individuals who develop TB meningitis, bacilli seed to the meninges or brain parenchyma, resulting in the formation of small sub-pial or sub-ependymal foci of metastatic caseous lesions, termed Rich foci. The second step in the development of TBM is an increase in size of a Rich focus, until it ruptures into the subarachnoid space. The location of the expanding tubercle (i.e., Rich focus) determines the type of the central nervous system (CNS) involvement. Tubercles rupturing into the subarachnoid space cause meningitis (6).

Currently, more than two billion people (i.e., one third of the world's population) are infected with TB, of which approximately 10\% will develop clinical disease. The incidence of TB is related to the prevalence of TB in the community, and it is still the most common type of chronic CNS infection in developing countries (6).

Although early and rapid identification of TB meningitis is crucial for successful disease management, in most of the cases, diagnosis is significantly delayed. Initial signs and symptoms of disease are non-specific, and the suspicion of TBM usually arises only some days or weeks after the disease's onset and is not different in children who have or have not been vaccinated with BCG. Fever, headache, anorexia, and vomiting characterize the prodromal of the disease in older children, whereas failure to thrive, poor appetite, vomiting, and sleep disturbances are more common in younger ones (7). Tuberculous meningitis is more easily suspected, when these symptoms are associated with a history of recent contact with a case of documented TB.

Walker et al. (9) reported that BCG vaccination is partially protective against TB meningitis; therefore, a history of $B C G$ vaccination or the presence of a $B C G$ vaccination scar affords some degree of reassurance, when considering a diagnosis of TBM. In patients in whom TBM is suspected clinically, the diagnosis must be rigorously investi- gated; a history of BCG vaccination does not rule out the diagnosis $(8,9)$.

In 1948, the British Medical Research Council developed a method for staging the severity of the disease, as follows:

- Stage I describes the early non-specific symptoms and signs including apathy, irritability, headache, malaise, fever, anorexia, nausea, and vomiting without any alteration in the level of consciousness.

- Stage II describes altered consciousness without coma or delirium, but with minor focal neurological signs; symptoms and signs of meningism and meningitis are present, in addition to focal neurological deficits, isolated CNS palsies, and abnormal involuntary movements.

- Stage III describes an advanced state with stupor or coma, dense neurological deficits, seizures, posturing, and/or abnormal movements.

The CSF modifications are common in children with TB meningitis. In these cases, CSF shows a clear appearance, moderate pleocytosis with a predominance of lymphocytes, an increase in protein content and a very low glucose concentration. These findings are different from those usually reported for typical bacterial meningitis in which CSF is opaque, pleocytosis is very high, and neutrophils are predominant. Reduction in glucose content is usually less marked in comparison to purulent bacterial meningitis, where CSF glucose values below $5 \mathrm{mg} / \mathrm{dL}$ will often be found. Clear appearance, white blood cell count between 50 and 500 per $\mathrm{mL}$ with $50 \%$ or more lymphocytes, protein content greater than $1 \mathrm{~g} / \mathrm{L}$ and glucose content less than $2.2 \mathrm{mmol} / \mathrm{L}$ are considered to be indicative of TB meningitis. However, atypical CSF findings have been repeatedly described in children with TB meningitis (8).

The ADA activity test is a rapid test which represents the proliferation and differentiation of lymphocytes as a result of the activation of cell-mediated immunity after TB meningitis. It yields good results in the diagnosis of the pleural, peritoneal and pericardial forms of tuberculosis. When applied to patients with TB meningitis, it was found that ADA activity could not distinguish between TBM and other types of bacterial meningitis; however, it could add useful information to suggest TB meningitis once meningitis due to different pathogens has been ruled out. The ADA valves from 1 to $4 \mathrm{U} / \mathrm{L}$ (sensitivity $>93 \%$ and specificity $<80 \%$ ) can help to exclude TB meningitis and values $>8$ $\mathrm{U} / \mathrm{L}$ (sensitivity $<59 \%$ and specificity $>96 \%$ ) can improve the diagnosis of TB meningitis $(p<0.001)$. However, 
values between 4 and $8 \mathrm{U} / \mathrm{L}$ are insufficient to confirm or exclude the diagnosis of TB meningitis ( $p=0.07)(10)$.

Similarly to clinical and laboratory findings, cerebral imaging can also contribute to diagnosing probable or possible TB meningitis. However, discrimination between TB meningitis and another cerebral disease is frequently very difficult. The most common brain CT or MRI features in children with TBM are hydrocephalus, which can be demonstrated in about $80 \%$ of cases, and basal meningeal enhancement, found in $75 \%$ of young patients. Infarction, as a result of ongoing vasculitis, particularly of the basal ganglia and of the areas of the medial striates and thalamo-perforating arteries and tuberculoma can be found in a smaller number of TBM pediatric cases. However, a combination of basal meningeal enhancement, infarction and hydrocephalus was found to have a high specificity for the diagnosis of TB meningitis, whereas basal meningeal enhancement was reported as the most sensitive feature (1 1).

The evidence of TB infection or disease outside the CNS can significantly increase the probability or possibility that a child with cerebral signs and symptoms can have TB meningitis. However, a great number of patients, particularly when HIV negative, will present with normal chest radiography or negative tuberculin skin testing (12). Moreover, particularly in high TB prevalence areas, a positive skin test with an unrelated illness has been frequently documented. Taking samples from sites of frequent TB infection such as lymph nodes, lung and gastric fluid can increase the likelihood of a positive culture. Gastric aspiration was positive in $68 \%$ of children with TBM (13).

Before the emergence of multidrug-resistant $M$. tuberculosis, three drugs were considered adequate for the first phase. More recently, to address the problem of resistance, four antibiotics for the initial months of treatment are preferred. However, there is no agreement on the duration of each of the two phases and on the total length of therapy. The intensive phase can range from two to six months and total treatment from six months to one year (14). For several years now, the drugs considered essential by the World Health Organization (WHO) to treat pulmonary $T B$ in children are isoniazid $(\mathrm{INH})$, rifampin (RMP), pyrazinamide (PZA), and ethambutol (EMB)(15).

World Health Organization regimen to treat Tuberculosis (15)

Isoniazid 10-15 mg/kg/24 h (max $300 \mathrm{mg}$ ) orally for 6 months
Rifampin 10-20 mg/kg/24 h (max $600 \mathrm{mg}$ ) orally for 6 months

Pyrazinamide $15-30 \mathrm{mg} / \mathrm{kg} / 24 \mathrm{~h}$ (max $2 \mathrm{~g}$ ) orally for 2 months

Streptomycin $20-40 \mathrm{mg} / \mathrm{kg}$ (max $1 \mathrm{~g}$ ) intramuscular or intravenous for 2 months

Prednisone $2 \mathrm{mg} / \mathrm{kg} / 24 \mathrm{~h}$ orally for 4 weeks, followed by a reducing course over $1-2$ weeks.

In meningitis, most of the damage derives from the immune response elicited by the presence of bacterial pathogens in the CNS. This leads to a very relevant inflammatory process with significant infiltrative, proliferative and necrotizing vessel pathologies. The best steroid and the most effective scheme of administration are not known, as no data comparing different regimens are available currently. Moreover, data collected in children are few. According to the suggestions of the American and European Scientific Societies, it can be suggested the use of oral compounds for three or four weeks with subsequent reduction in few days $(16,17)$.

Issues needs to be considered-

1. BCG Vaccination and role in preventing pediatric disseminated tuberculosis (6)

Following exposure to tubercle bacilli, it takes about 6 to 8 weeks for a primary complex to develop. Six to twelve months after the primary infection, tuberculous meningitis, secondary to hematogenous spread, may occur. The commonest age group for tuberculous meningitis is nine months to three year. BCG vaccination prevents hematogenous dissemination and development of TBM to the extent of $60-80 \%$. Immunity following vaccination takes about eight to ten weeks to develop during which interval exposure to tubercle bacilli can cause disseminated infection. Hence BCG vaccination is must in all the newborns in high TB prevalence setting particularlyin India (6).

2. Role of Tuberculin test (18)

The standard tuberculin test recommended for use is the Monteux's test. Commercially available tuberculins in the country are one, two and five Tuberculin Unit (TU) PPD (RT23 equivalent). It is important to raise a wheal of about $6 \mathrm{~mm}$ after the intra-dermal injection and the test is read 48-72 hours after an injection. Ballpoint or palpatory methods are used to read the induration. The width of reaction (induration) in the horizontal plane is noted for interpretation. The Monteux's test or PPD skin test is considered positive, if the duration is $10 \mathrm{~mm}$ or more. This cut-off was recommended using a 1 TU PPD RT23. Currently, the laboratories more often use 5 TU PPD (RT23 equivalent), or sometimes even some other higher 
strengths or types of PPD are used. The standard cut-off of $10 \mathrm{~mm}$ can actually not be justified for any higher strength of PPD used. The reaction evoked is not only dependent on the amount of antigen given, but also does not have a linear relationship with the increasing strengths. Therefore, the current practice may actually lead to an increase in false positive reactions using the 10-mm cut-off with the higher strength of PPD. Efforts should be made to use only 1 TU PPD to decrease the false positives and in no case strength higher than 5 TU should be used. The degree of reaction, including necrosis and ulceration, may not necessarily differentiate infected from diseased (18).

3. INH prophylaxis (19)

TB preventive therapy: The dose of INH for chemoprophylaxis is $10 \mathrm{mg} / \mathrm{kg}$ (instead of currently recommended dosage of $5 \mathrm{mg} / \mathrm{kg}$ ) administered daily for six months. TB preventive therapy should be provided to:

a. All asymptomatic contacts (under six years of age) of a smear positive case, after ruling out active disease and irrespective of their BCG or nutritional status.

b. Chemoprophylaxis is also recommended for all HIV infected children who either had a known exposure to an infectious TB case or are Tuberculin skin test (TST) positive ( $\geqslant 5 \mathrm{~mm}$ induration), but have no active TB disease.

c. All TST positive children who are receiving immunosuppressive therapy (e.g. children with nephrotic syndrome, acute leukemia, etc.).

d. A child born to mother who was diagnosed to have TB in pregnancy should receive prophylaxis for six months, provided congenital TB has been ruled out. BCG vaccination can be given at birth, even if INH chemoprophylaxis is planned.

\section{CONCLUSION}

Tuberculosis in a child represents recent and ongoing transmission of TB bacteria. Young children particularly below six years of age are most likely to become exposed and infected with TB by close contacts, such as family members. A high index of suspicion is must while evaluating these cases and all possible measures should be taken to confirm tuberculosis to have successful treatment outcome. Extra-pulmonary tuberculosis (EPTB) is fairly more common in pediatric cases with CNS involvement a predominant site.

The BCG vaccination is must to all newborns in India, as it will prevent childhood TB and its complications. Tuberculin skin test has valuable role in childhood TB as it is one of the indicators of active disease, irrespective of
BCG vaccination in pediatric cases below six years in high TB burden country such as India. The INH prophylaxis has best possible measure in close contacts of known sputum positive case, and to be considered routinely to all pediatric cases after ruling out active TB.

Response to ATT is excellent, compliance is adequate and with insignificant side effects in pediatric cases. Duration of treatment and treatment outcome is similar to adults. We recommend extended regimens for EPTB, i.e. up to 12 months in TB meningitis cases.

\section{CONFLICTS OF INTEREST}

None declared.

\section{AUTHOR CONTRIBUTIONS}

Concept - S.P., N.N., C.R.C.; Planning and Design - S.P., N.N., C.R.C.; Supervision - S.P., N.N., C.R.C.; Funding S.P.; Materials - S.P.; Data Collection and/or Processing - S.P.; Analysis and/or Interpretation - S.P.; Literature Review - S.P.; Writing - S.P.; Critical Review - S.P.

\section{YAZAR KATKILARI}

Fikir - S.P., N.N., C.R.C.; Tasarım ve Dizayn - S.P., N.N., C.R.C.; Denetleme - S.P., N.N., C.R.C.; Kaynaklar - S.P.; Malzemeler - S.P.; Veri Toplama ve/veya İşleme - S.P.; Analiz ve/veya Yorum - S.P.; Literatür Taraması - S.P.; Yazıyı Yazan - S.P.; Eleştirel İnceleme - S.P.

\section{REFERENCES}

1. Global Tuberculosis Report", WHO, Geneva, 2015 www.who.int/tb/publications/global report/en/.

2. "Childhood Tuberculosis Roadmap", 11th November 2012 www.stoptb.org.

3. Garcia-Monco JC. Central nervous system tuberculosis. Neurologic Clinics 1999; 17:737-60. [CrossRef]

4. Lewinsohn DA, Gennaro ML, Scholvinck L, Lewinsohn DM. Tuberculosis immunology in children: diagnostic and therapeutic challenges and opportunities. Int J Tuberc Lung Dis 2004; 8:658-74.

5. Farinha NJ, Razali KA, Holzel H, Morgan G, Novelli VM. Tuberculosis of the central nervous system in children: a 20-year survey. J Infect 2000; 41:61-8. [CrossRef]

6. Udani PM. Management tuberculous meningitis. Indian J Pediatr 1985; 52:171-4. [CrossRef]

7. Khemiri M, Bagais A, Becher SB, Bousnina S, Bayoudh F, Mehrezi $A$, et al. Tuberculous meningitis in Bacille Calmette-Guerin-vaccinated children: clinical spectrum and outcome. J Child Neurol 2012; 27:741-6. [CrossRef] 
8. Starke JR. Tuberculosis of the central nervous system in children. Semin Pediatr Neurol 1999; 6:318-31. [CrossRef]

9. Walker V, Selby G, Wacogne I. Does neonatal BCG vaccination protect against tuberculous meningitis? Arch Dis Child 2006; 91:789-91. [CrossRef]

10. Tuon FF, Higashino HR, Lopes MI, Litvoc MN, Atomiya $A N$, Antonangelo $L$, et al. Adenosine deaminase and tuberculous meningitis - a systematic review with metaanalysis. Scand J Infect Dis 2010; 42:198-207. [CrossRef]

11. Theron S, Andronikou S, Grobbelaar M, Steyn F, Mapukata A, du Plessis J. Localized basal meningeal enhancement in tuberculous meningitis. Pediatr Radiol 2006; 36: 1 182-5. [CrossRef]

12. Akhila K, Mahadevan S, Adhisivam B. Qualitative evalvation of tuberculin test responses in childhood tuberculosis. Indian J Pediatr 2007; 74:641-4. [CrossRef]

13. Doerr CA, Starke JR, Ong LT. Clinical and public health aspects of tuberculous meningitis in children. J Pediatr 1995; 127:27-33. [CrossRef]
14. Donald PR. The chemotherapy of tuberculous meningitis in children and adults. Tuberculosis (Edinb) 2010; 90:375-92. [CrossRef]

15. Treatment of tuberculosis: guidelines - 4th ed. World Health Organization 2010.

16. Centers for Disease Control. Treatment of tuberculosis. MMWR Recomm Rep 2003; 52:1-77.

17. Thwaites G, Fisher M, Hemingway C, Scott G, Solomon $T$, Innes J. British Infection Society guidelines for the diagnosis and treatment of tuberculosis of the central nervous system in adults and children. J Infect 2009; 59:16787. [CrossRef]

18. Chadha VK. Tuberculin test. Indian J Pediatr 2001; 68: 53-8. [CrossRef]

19. IAP Working Group. Consensus statement of IAP Working Group: status report on diagnosis of childhood tuberculosis. Indian Pediatr 2010; 41:146-55. 